\title{
Persons without capacity as participants in research: A Kingdom perspective on article 7 (b) of UNESCO's Universal Declaration on Bioethics and Human Rights (2005)
}

\author{
Rheeder, Riaan \\ North-West University \\ Riaan.Rheeder@nwu.ac.za
}

\begin{abstract}
In 2005, UNESCO's Universal Declaration on Bioethics and Human Rights (UDBHR) was accepted unanimously by the world community (191 member nations). The declaration is currently the first and only bioethical text to which the entire world has committed. However, this document, particularly Article 7(b), is not of religious origin and must therefore be evaluated from a Christian point of view. This article strives to ground the ethical and human rights issue of substitute consent with regard to research with persons without capacity from a Protestant perspective. The grounding is performed in the light of the theme of the Kingdom of God.
\end{abstract}

Keywords

Kingdom of God, health, healing, research, human rights, incapacity, UNESCO

\section{Problem statement}

This theological study examines Article 7(b) ('Persons without the capacity to consent') of the Universal Declaration of Bioethics and Human Rights (hereafter UDBHR):

In accordance with domestic law, special protection is to be given to persons who do not have the capacity to consent:...(b) research should only be carried out for his or her direct health benefit, subject to the authorization and the protective conditions prescribed by law, and if there is no research alternative of comparable effectiveness with research participants able to consent. Research which does not have potential direct health benefit should only be undertaken by 
way of exception, with the utmost restraint, exposing the person only to a minimal risk and minimal burden and if the research is expected to contribute to the health benefit of other persons in the same category, subject to the conditions prescribed by law and compatible with the protection of the individual's human rights. Refusal of such persons to take part in research should be respected (UNESCO 2006).

The UDBHR is in my view one of the most important instruments in the history of human rights (and bioethics) because it was accepted unanimously by the global community (191 member countries), which means that the declaration is the first and currently the only political bioethics text that all the governments of world have agreed to, including South Africa (UNESCO 2005).

It is a true that some persons do not have the capacity to give informed consent to a research project, but may be considered for research. The need for a global bioethics for research was among other things demonstrated by the well-known Trovan case (1996). American researchers of a prominent pharmaceutical company experimented with medicine on children with Meningitis in Kano, Nigeria, without any informed or substitute consent from the parents of the children, while other effective medicine was available. Eleven children died as a result of the experiment (Ten Have 2011:146-165). UNESCO developed Article 7(b) to solve this type of problem by formulating human rights principles according to which substitute consent can be provided with a view to research (Gefenas \& Tuzaite 2014:85).

Tham (2014:2) commenting on the UDBHR points out the following: 'By its very nature, United Nations documents tend to be non-religious and nonsectarian.' He indicates that over the course of a long development process and much debate within UNESCO, there was only one opportunity for religious communities to make an official contribution to the UDBHR. $\mathrm{He}$ adds that there was no contribution from the Protestant tradition. Although there was some involvement of the great religions of the world in the process of drafting the declaration (Islam, Confucianism, Hinduism, Roman Catholicism and the Jewish tradition), Article 7(b) was not developed or declared within a Christian paradigm and it is therefore not Christian in origin (IBC 2004:2-4; Ten Have \& Jean 2009:31). The absence of 
religious grounding conforms to the universal character of global bioethics and human rights, which necessitates pre-formulated principles or abstract ideals that are accepted by all nations, but are not based on any specific philosophy or religion and that is not linked to any theoretical foundation.

The non-religious and universal character of the UDBHR poses a problem to Christians whose life and world view is grounded in Biblical principles. Although the doctrine of natural law makes universal values possible, it is a presupposition in this article that human rights cannot be handled as if they were a-religious concepts, because the human being as a religious being cannot ultimately be free of religious preconceptions. Significantly, the importance of a religious debate, specifically on Article 7(b), is recommended by UNESCO itself, as stated by the IBC (International Bioethics Committee of UNESCO) after several religions have participated in the debate on the UDBHR (Tham 2014:2):

At the end of this session, the moderator of the panel lamented that it is a pity UN organizations do not pay more attention to religion since a great majority of the world's population is affiliated with some religious traditions.

The need for religious grounding is addressed by Tham (2014:2) in his introduction to The Principle of Vulnerability: Meeting Ground of Six Religions: 'In this volume, however, we wish to supplement...from different religious perspectives'.

This article is written from a Christian perspective, specifically the Protestant view that all values should be evaluated in the light of the Word and of Christ (Ephesians 5:1; 2 Corinthians 10:5; Van Wyk 1998b:171). This viewpoint is explicitly set out by the Protestant human rights expert and ethicist J.M. Vorster (2015:109), who links the Bible with human rights instruments in his argument that the second commandment compels knowledge of and living according to the Word. He continues, 'This lies an important foundation for Christian moral action. Ultimately the written Word offers the principles for ethics and forms the acid test for all ethical codes and actions.' 'Protestant' is used in the broad sense of the Christian tradition that originated in the sixteenth century and currently constitutes the third largest Christian tradition, Roman Catholicism and Greek Orthodoxy being the two larger traditions. Protestantism is diverse and comprises diverse viewpoints, but two features form the 
core of the tradition, namely emphasis on the Word of God and protest against injustice, e.g. protest in favour of religious freedom (Van Leeuwen 2014:420-423). The aim of this article is to investigate the possibility of a Christian foundation for Article 7(b) of the UDBHR.

The Christian grounding of universal bioethical (and human rights) principles is a new development in Protestant theology and has been introduced by Macaleer (2014), who clearly shows that no Protestant ethicist has as yet given in-depth attention to a theoretical framework for modern global bioethical principles. His book (or thesis), The New Testament and Bioethics: Theology and Basic Bioethics Principles, deals with the theoretical grounding of four universal bioethical principles as formulated by Beauchamp and Childress (2013, autonomy, beneficence, maleficence and justice). Macaleer (2014) summarises these as follows:

As outlined by Beauchamp and Childress, these principles are based on what they call the common morality. Thus, the principles have no specific theological foundation; this book attempts to give those principles a Scriptural foundation.

The same approach could be adopted for all the universal principles of the UDBHR with no theological foundation, amongst others the principles relating to persons without the capacity to consent. In light of the above-mentioned remark, a Biblical grounding is of special value for the Christian physician and researcher, because a Christian foundation forms the religious motivation for recognizing and exercising a human right. Grounding forms part of 'I believe in'. It will help that human rights, as J.M. Vorster recommends, live in the heart of the Christian (Vorster, 2004:24).

Macaleer (2014:148-149), who offers a theological foundation for the abovementioned modern human rights and universal bioethical principles, uses the method of first explaining the principle and then following the explanation up with the founding. The same method will be implemented in this article by first identifying and explaining the principle of capacity without consent in Article 7(b) and then suggesting a possible Scriptural foundation for the principle. The Scriptural foundation will be searched for within the theme of the Kingdom of God.

Before discussing Article 7(b) on capacity without consent in detail, the following remarks on the intended audience and scope of the UDBHR should be noted: 
Langlois (2013:154), who studied the reception of the UDBHR in South Africa and Kenia, says the following: 'The Universal Declaration helps put bioethics on the agenda of States ... It appears to have had little or no impact in South Africa, however, on what is a growing and developing bioethics community.' The important fact emerging from the above quotation is that unlike all the other bioethical instruments, the UDBHR is particularly directed at developing countries. ${ }^{1}$ However, there is much room for developing bioethics in South Africa, as it is important to take into account that the establishment of an ethos of human rights in the country will depend on the understanding of (and agreement with) the fundamental content of the UDBHR by all citizens.

Furthermore, international literature on bioethics and human rights is not the main field of interest in this article, but the focus is exclusively on the Universal Declaration of Bioethics and Human Rights and UNESCO's related literature with the aim of determining a UNESCO perspective (and per implication that of the global community).

Early on in the development of article 7 of the UDBHR, a distinction was made between consent with a view to medical practice (Art. 7a) and consent to research (7b) (IBC 2008:28; Martin 2009:142-143). This study only pays attention to consent with a view to research. UNESCO itself makes this distinction in its declaration (UNESCO 2008:34, 36).

In the light of the above discussion, the central theoretical statement of this study is that substitute consent with a view to research can be founded on the theme of the Kingdom as part of God's rule.

The content of Article 7(b) as interpreted by UNESCO is subsequently discussed and evaluated with a view of identifying underlying principles of substitute consent.

1 'The aims of this Declaration are [...] to promote equitable access to medical, scientific and technological developments as well as the greatest possible flow and the rapid sharing of knowledge concerning those developments and the sharing of benefits, with particular attention to the needs of developing countries [...]' (UNESCO 2006, art. 2f). 


\section{Global right}

\subsection{Protection}

Article 7(b) deals with the special protection of the person who does not have the capacity to provide consent for research (UNESCO, 2006). Incapacity is indicated in the first instance as a reason why special protection is needed. The truth is that there are individuals who do not have the capacity or ability to make autonomous decisions (IBC 2008:28). The Bioethics Core Curriculum defines incapacity as follows (UNESCO 2008:34):

Incapacity can be defined as lacking the freedom to make authentic decisions because of an inability to make such decisions even when given the opportunity.

It should be said that UNESCO reveals that there is no international consensus on what the definition of incapacity precisely entails. In general, the above definition indicates the following categories of people: newborns, younger and older children, the mentally ill, intellectually disabled persons, confused elderly persons and people who are unconscious (Gefenas \& Tuzaite 2014; IBC 2008:28; UNESCO 2008:35; Martin 2009:145). Human dignity, in the second instance, forms the motivation for special protection when research is considered. The above statement is confirmed by article 2 of the UDBHR, which states that the goal of the declaration is among other things 'to provide a universal framework of principles' with the specific aim 'to promote respect for human dignity' (UNESCO 2006). Article $7(\mathrm{~b})$ is a plea that persons without capacity ('persons who do not have the capacity to consent') have human dignity and should be treated as such. Said differently, a human being's dignity is not dependent on the quality of his or her autonomy (Martin 2009:140). In the third place, substitute consent is accepted by the global community as the method of protection. Protection is understood to mean that 'authorization for...research should be obtained' (Martin 2009:142; UNESCO 2013:78). This authorization refers to substitute consent (IBC 2008:28-29,32), which means that another person or body provides consent for the research on behalf of the relevant person. 


\subsection{Guidelines}

No research may take place without the official consent of a legal guardian or body ('subject to authorization'). This consent includes the consent of a legal ethics committee (Art. 19, UNESCO, 2006). Gefenas and Tuzaite (2014:86-87, 98) are of the opinion that there is consensus within the global bioethical discourse on the fact that consent may not be left to the arbitrary autonomy of the substitute, but that it should be authentic ('autonomy as authenticity'). It means that consent for research should only (UNESCO 2006) be given if the research project meets certain requirements and authoritative norms (IBC 2008:28; Martin 2009:150).

\subsubsection{Direct benefit}

The first requirement makes research with persons without capacity possible in cases where a direct health benefit (as first norm) is in view ('research should only be carried out for his or her direct health benefit'; UNESCO 2006). Against the background of the Nazi research delicts, where research was done on children or adults without the capacity to give informed consent (UNESCO 2013:76-79), the Nuremberg Declaration (1947) responded radically by only allowing research where persons have the capacity to give informed consent. The exclusive application of informed consent has resulted in a situation where no research on children or adults with incapacity could be considered (Gefenas \& Tuzaite 2014:99; Martin 2009:142, 147). This situation resulted in the earlier declarations of Helsinki (1964-1989) tempering the Nuremberg view by distinguishing between therapeutic and non-therapeutic research in 1964 (Kelly et al 2013). This mediation has made it possible to consider persons without capacity for research, but only where there is a direct benefit for the participant (Gefenas \& Tuzaite 2014:99).

This guideline makes the later phases in research possible where a direct health benefit is available. This means that during phase 2 and 3 investigations (phases after testing with animals or people that can consent), where research primarily examines the efficacy of medication, persons without capacity may be considered and the research can in this way contribute to the (sometimes limited) direct health of such persons.

Research activities that include children are needed to understand the physical and psychological development of children, childhood diseases, 
psychiatric problems and potential pharmacological interventions. This principle especially makes research possible in the totality of the life sciences, since there are often direct pedagogical (for instance learning problems) and psychological (behavioural problems) benefits for the participants without capacity (see Art. 1; UNESCO 2006). It is a wellknown fact that children in Africa often do not take their prescribed AIDS medications. A religious quantitative and qualitative investigation among children can for instance try to determine the reasons for not taking the medicine and to develop a theological foundation and programme that activates the religious community to assist children in this regard contributing directly to the health of the child in this way. Adults with incapacity also need the results of research. In this regard, one can think of persons with psychiatric problems like dementia. Research is necessary to determine how these conditions affect specific persons or how effective the medication is. The same goes for degenerative neurological diseases (for instance sclerosis) (Martin 2009:151; UNESCO 2008:35). It is clear that the above examples give expression to the second norm that there is 'no research alternative of comparable effectiveness with research participants able to consent' (Art. 7(b)). Adults cannot replace children and healthy adults cannot be considered to test experimental medicine meant to treat persons with for instance dementia or sclerosis. The principle of benefit also wants to avoid the use of persons with incapacity as an easy and expedient substitute due to a lack of or unwillingness among persons with capacity: 'It is not sufficient that there should be no capable volunteers. Recourse to research on persons not able to consent must be, scientifically, the sole possibility' (Europe 1997, Art 17, par. 104; UNESCO 2006).

\subsubsection{No benefit}

The second requirement makes research possible where there is no prospect of a direct health benefit ('Research which does not have potential direct health benefit should only be undertaken by way of exception, with the utmost restraint' - UNESCO 2006). The first norm (resulting from the first requirement) does not leave room for early phase research (with its focus mainly on toxicity and pharmacokinetic information), where the direct benefit to the individual participant is absent or extremely limited (Gefenas $\&$ Tuzaite 2014). Phase 1 research would not be considered in the case of children or incapable adults (Europe 1997, art. 17, par. 107). This situation 
lead to further mediation in 1990, which had the result that research without direct benefit could be considered. In their Bioethics Core Curriculum, Section 2, UNESCO refers to the possibility of the use of new experimental medicine of which the safety is uncertain in the treatment of CreutzfeldtJakob's disease (fatal brain disorder) in children and adults, a condition for which no prevention or cure currently exists (UNESCO 2011:34-35). This principle also makes research on newborn children and the phenomenon of coma possible (Martin 2009:141) (Europe 1997, Art. 17, par. 113). 'Any restriction based on the requirement of 'potential direct benefit' for the person undergoing the test would make such studies impossible in the future' (Europe 1997, Art. 117, par. 112). Clearly, research of this nature would probably contribute to the health of future patients in the same category of diseases, which can all be viewed as exceptions that constitute the first norm flowing from the second requirement (UNESCO2006, Art. 7(b)).

A second norm resulting from the second requirement is also valid, namely that research may only take place when it meets the minimum risk and minimal burden criterion (UNESCO 2006). According to Martin (2009:141), the minimum means that 'the research project might cause only an insignificant and transient alteration of health status (risk) and only transient and negligible symptoms or inconveniences (constraints)'. Examples of research with minimum status include computerised tomography, ultrasound scanning, $\mathrm{X}$-rays, magnetic resonance imaging without a contrast medium, gathering of data by means of interviews and observations, non-interfering collection of body fluids like sputum, urine and smears and taking small numbers of tissue or blood samples during interventions that form part of acceptable treatment (Europe 1997; Martin 2009:141).

A new core characteristic establishing a third norm (as declared in Art. 7a) suggests that in the case of a person without capacity, the person should be involved in the decision-making process as far as possible. This characteristic sets the principle of participatory decision-making ('the person concerned should be involved to the greatest extent possible in the decision-making process of consent'). Participatory consent is firstly aimed at people with limited incapacity and aims to respect the principle of autonomy as far as possible (Art. 5, UDBHR). It sets the guideline that children, persons with learning disabilities and psychiatric conditions cannot be excluded or 
estranged from the decision-making process as a matter of course (Martin 2009:144-145; Gefenas \& Tuzaite 2014:87). It is also important to indicate that the UDBHR states the principle of refusal to participate together with the principle of participatory decision-making ('Refusal of such persons to take part in research should be respected'; Europe, 1997; IBC 2008:16).

The discussion subsequently turns to the concept of global protection from a Biblical perspective.

\section{A Biblical perspective}

\subsection{Kingdom as theme}

In a Protestant evaluation of the right to substitute consent with a view to research, one should work carefully with the Bible. In the past, the Bible has been abused in different ways (2 Peter 3:16), but abuse does not preclude all good use (Douma 1997:39). One should guard against Biblicist use of the Bible, because a literal interpretation can lead to incapacity being seen as impurity, demonic or immoral (see Leviticus 21: 16-23; Matthew 9: 32-33; Ephesians 4:18; Cochran 2011:232; Ucko 2014:148). How does founding take place? Macaleer $(2014: 10,14,212)$ points out that the concept 'consent for persons without capacity' as a theme does not appear directly in the Bible, because $21^{\text {st }}$ century bioethical concepts did not form part of the New Testament worldview (Verhey 2011:96). The well-known Protestant ethicist, JF Childress (2002), starts his penetrating evaluation of informed consent with a view to research with the following statement:

Which Protestant beliefs lend support to standards of selfdetermination (autonomy) and voluntary, informed consent/refusal in clinical care and research? Methodologically, Protestants have tended to downplay tradition in favour of direct appeals to Scripture, and they have found in, or developed from, Scripture several key themes.

Several Protestant theologians such as Macaleer (2014:ix-x), Douma (1997:41) and N. Vorster (2003:240) support a thematic treatment of Scripture as part of ethical considerations. The Biblical doctrine on the Kingdom of God has become a very important theme in the twentieth century and one can see it as the over-arching theme or central motif from 
which all other Biblical themes result. The concept of the Kingdom includes the entire message of the Bible, and within this framework relevant themes are formulated that serve as a foundation for Christian ethics. This point of departure is seen as a new paradigm of ethics within Protestant / Reformed theology. The theme of the Kingdom is of crucial importance for ethics and for a Christian life. Christian ethics is also Kingdom ethics (Van Wyk 2015; J.M. Vorster 2015). Macaleer (2014:76-147) identifies the human being as the image of God, the covenant and healing as themes within this central perspective of the kingdom of God. These themes together form a Christian theory for substitute decision-making, and therefore Kelly et al (2013) are correct when they write, 'They are hermeneutic themes, not ethical rules.'

\subsection{Kingdom of the Father}

Scripture emphasises God's rule in the church and the world. The Kingdom of God is a future reality of complete transformation where God has made everything new and where people will have complete health (Revelations $21: 5 ; 22: 3)$. However, the Kingdom is not only a future reality, but is also a current reality, and both the Old and the New Testament emphasise this reality (Green 1995:530; Psalm 93:1; Matthew 3:2, 1:31; Ephesians 5:5). Jesus' coming to earth and his suffering, death and resurrection serve as visible signs of the Kingdom (Mark 1:15): '...powers of the coming age break into the present... He comes announcing and demonstrating the Kingdom... the future becoming present, or inaugurated eschatology...' (Morphew, 2015, loc 567, 628). The current character of the Kingdom forms a central theme in the preaching of Christ (Matthew 4:17; Acts 1:3) and is described as the gospel of the Kingdom (Matthew 4:23; 9:35).

The Bible presents God as the Creator-King of heaven and earth (Isaiah 44). His present rule over one and all (church and world) stretches into an eternal rule that includes the past, present and future (Ps 103: 19, 22; 145: 10, 13; Lk 1: 32-34; Mt 28: 18; 1 Cor 15: 27; Col 1: 13, 16). Jesus' ministry of healing to heathens also shows the universal character of God's rule (Mt 8:7-13; Morphew, 2015, loc 592-603, 712). God Triune as King of the universe is the fundamental personal force, who manages history with struggle, victory and sustenance to its ultimate completion. With his rule, God wants to promote the common good; in this way, something of the future glory is already visibly realised now (Rom 12:17-18; 14:17; Van Wyk 2015:217; N. Vorster 2007:134). The universal feature of the rule of God also 
serves as foundation for natural law, which brings shalom to the whole of creation (Green 1995:531). It is clear that the Kingdom of God is not only soteriologically directed (N Vorster 2007:28), but is also aimed at the socioethical. The King did not only create heaven and earth, but also created the human being as his viceroy (Gen 1:26-28) with the goal that he or she should rule like God (Morphew 2015, loc 930). The human being as viceroy was created in the image of God, which means that the human has been equipped with great power and glory, so that he or she can rule as viceroy of creation (Ps 8; Hebrews 2:5-8).

Five matters are of importance here. In the first place, God not only rules creation directly, but also exercises his rule over all of creation through humans. In the church, which consists of people who accept the rule of God (Is 26:13; Moltmann 2012, loc 446), believers are co-workers in the rule of God (2 Cor 6:1; Col 4:11). The citizens of the Kingdom have the task of serving each other (Matthew 24:46; Mark 10:43-45) and making God's rule visible in this way. The citizens of the church have the task of spreading the Word in the church and to equip each other in this way (Eph 4:11-12; J.M. Vorster 2011:39) with the aim of serving each other. The equipped believer not only has a task within the church, but also has a responsibility towards the world and society. In his in-depth discussion of the Kingdom, Van Wyk (2015) derives this task from Christ's call that believers should be the salt and leavening of the earth (society) (Mt 5:13; 13:31-33). This means that believers should not be like oil that floats on water, but should enter society and positively influence it. The same goes for leavening. 'Invisible like salt, leavening does its penetrating job until the flour has been completely (holon) leavened,' Van Wyk (2015:220) writes. (See also Matthew 5:13-14; Morphew 2015, loc 555.) In the world, God also rules through innate natural law in all people (Romans 1:28; 2:14-15). In the Kingdom of God, secondly, the human dignity of every person as viceroy is derived from the fact that the human being has been created in the image of God. Being God's image brings the human being especially close to God (König 2001:100-101; JM Vorster 2004:91-92). In this hierarchy of existence, God is axiomatically the highest form of existence and dignity (Higginson 1995:98), and therefore He is praised in Revelation 4:11 as the worthy ( $\dot{a} \xi$ เów) (also see Hebrews 3:3). If God is absolute dignity and the human being is his image, the human has derived, but definite value in 
the Kingdom (Matthew 6:26; 2 Peter 1:4). 'If God can become a man, how great can man be?' Morphew (2015) says poignantly. Protestant bioethicists agree in the third instance that being the image of God means that man is an autonomous being because God is free (Childress 2002; VanDrunen 2009:43). Barth (1976:301-302) founds God's freedom on concepts such as, 'I am the Lord', 'I am the Lord your God' (Isaiah 45) and the words of Jesus 'I am' (John 8). The Kingdom of God is characterised by freedom (Rom 14:13-33; Van Wyk 2015:198).

Since the human being is, in the fourth place, the image of the living God (Genesis 9:6; 1 Timothy 3:15), human life should be respected (Frame 2008:685; Nullens 2013:62), which brings with it the duty that life may not be harmed or disadvantaged in any way, be it physically or psychologically (Ex 20:13, 21:18-3; Matthew 5:22; 10; Rom 13:8-10; Childress, 2002; De Bruyn 1993:134; Frame 2008:689; Nullens 2013:62-63). For this reason, human beings are compelled to refrain from doing any harm whatsoever (1 Thessalonians 5:21). People in general, but vulnerable people in particular, should be protected against the evil of others (see Ps 72:12-14; Verhey 2013:1-14; Macaleer 2014:172, 180). Human dignity is also the reason why Christian ethics emphasises the protection of vulnerable people so much (see Ex 22: 21-23; Lev 19: 33-34; Amos 5: 21-24; 1 John 3: 17; O’Mathúna 2014:255; Verhey 2013:1-14). In the fifth instance, Heyns (1986:290) links the human being as the image of God, Kingdom and science (research as obtaining reliable knowledge, truth, coherence, relevance, usefulness, Colossians 3:10) (see Kelly et al 2013) to each other, when he argues that the primary purpose of scientific work by the human being as the viceroy is the glorification (or acknowledgement as Lord) of God, with the secondary purpose of making the earth inhabitable through healing (Is 44:6; 45:18). Research aims to take superficial, naive knowledge to deeper responsible knowledge.

The rule of God should be understood within the context of the fall of the human being (Gen 3). The basic message of the Bible is that everything God created was good (Gen 1-2), but that the world has inexplicably fallen into the hands of sin and evil. In this regard, Genesis 3 points to the fact that the human being sins against God, Genesis 4 reveals the reality of wrongdoing towards fellow humans, while Genesis 6 shows the violent nature of $\sin$ (Gen 6:11-12). The point of this creation narrative is precisely 
to confess the immense reality of loveless evil: people infringe on each other's physical and psychological integrity and the research environment is not excluded from this lack of respect (Amos 1:13; Mk 5:5, Mt 24:49, 27:30, Acts 21:32; 1 Cor 8:12; McGrath 1995:32; Sentamu 1995:835-854). Illness, incapacity and death are also results of the fall (Cook 1995:436). Illness can be seen as a precursor of death (Atkinson 1995:90) and a way in which death (in varying degrees) already lays claim to life during our existence. Illness is a sign of death. According to the Bible, someone who is ill is already 'in death', and someone who has been healed 'has been resurrected' (Ps 30:2-3; König 2001:184-186). Both the realities of evil and illness call for protection and healing (Ps 6; Jer 17:14), something that God promises now and in future as a reality (Mal 4:2; Hurding 1995:431); these realities yearn for the Kingdom of God. In spite of the fact that incapacity is the result of the fall of the human being, one can accept that all people within the Kingdom have been created in the image of God, regardless of physical or psychological capacity (Ucko 2014:147). In the Kingdom, there is no difference in value between people (Galatians 3:28; Colossians 3:11; Morphew 2015, loc 543). According to Macaleer (2014:172, 189), there are no Biblical grounds to view persons without capacity as less dignified. He puts it as follows: 'Even those who are severely mentally disabled and are unable to communicate with others, still bear at some level the image of God.' From a Protestant perspective, both Cochran (2011:232) and Ucko (2014:150) are of the opinion that the human dignity of the person without capacity is ratified by the theological meaning of the crucified Christ. On the one hand He is the 'disabled body', the broken Man without capacity; on the one hand, He remains the image of God (Mt 26:26; Col 1:15).

Against the background of the reality of the sin and potential evil that people can inflict on one another within the research environment, God also promises a universal system of justice as a global ethic by means of which the citizens of the world can take care of each other and protect each other as a mode of God's rule. According to VanDrunen (2009:33; 2014:99-100), God's relationship (Noahic covenant) with the world forms the background to understanding natural law. The Bible reveals the development of a universal justice system with the aim of ruling a diverse and broken human existence after the fall of the human being. König (2010:113-14) and Van Wyk (1998a:176) indicate that Genesis 1-11 deals 
with universal human history and should be understood as follows: firstly, God is universally involved from the beginning (or in a covenant with all of humanity or all living beings, Genesis 9:16), and secondly, the section deals with matters that humanity has in common (Kelly et al 2013, JM Vorster 2004:42). The manner of the involvement and commonality that König does not mention explicitly is made clear by VanDrunen (2009 31-33):

Genesis 4:15 and 9:6 are particularly relevant. In both of these texts, God ordains a system of human justice not as the sole possession of those who believe in Him, but as the common possession of the human race.

Genesis 4 and 9 indicate that God provides earthly authority in the form of universal codes with the aim of protecting man and creation against evil (N. Vorster 2007:108). In this sense, the world is brothers and sisters of each other (Amos 1:9), with the collective goal of promoting peace and stability in a diverse and secular world (Jeremiah 29:4-7; Romans 12:18) and doing good to all people (Galatians 6:10) by means of a universal system of law and justice (Is 32:17; Ps 85:11; James 3:18; Van Wyk 1991:259). This system of universal human justice is unlocked by natural law, amongst others, and it serves as the foundation of human rights in the transcendent (Morphew 2015, loc 533). From the discussion thus far, it is clear that God wants to manage the world within the context of evil through universal codes that are aimed at protecting all people, also those without capacity (Mazur 2012).

\subsection{Kingdom of the Son}

Against the background of sin and the goal of the Kingdom to promote the good, the rule of God in Christ forms a unit that consists of two related aspects. On the one hand, God confronts, fights and conquers evil, sin and all forms of death in life. Right through the Old Testament, God condemns evil (Is 59:7, Jer 22:3). The New Testament focuses the attention on the close link between the rule of Christ and his service on the cross (Col 1:13, 20). Jesus Christ, who now works as Curios over heaven and earth, has broken the power of evil in the form of sin, death and the devil (Jn 12:31; 16:33; 1 Cor 15:24-26; Col 1:13-14; 2:15; Rom 6:1-7; Heb 2:14) (Morphew 2015 loc 696). This means that evil such as illness is disarmed in Christ, which implies the promise that these illnesses can be conquered and healed in this present 
time (N Vorster 2007:134-135). In this regard, Heyns (1986:291-302) speaks of research as part of Christ's grace that helps man to bring about healing in a responsible manner.

On the other hand, the nature of the rule of Jesus is that He brings life from death through healing (J.M. Vorster 2004:217-218). There is an especially close link between the rule of Christ and healing throughout the entire Bible, and this forms a crucial part of the rule of God on earth (Verhey 2011:99; Morphew 2015, loc 578). Healing describes the character of the Kingdom (Green 1995:531). Healing forms such an important theme in the Kingdom that healing and taking care of an ill person is viewed as taking direct care of the invisible Jesus himself (Mt 25:31-46; Moltmann 2012, loc 412; Morphew 2015). In the Old Testament, God is indicated as the Healer (Ex 15:26) that heals people physically (2 Kgs 4:32-35; 5:14), psychologically (Is 57:18-19), spiritually (Ps 103:3) and socio-economically (Job 42:12-17) through different means (2 Kgs 4:32-35; 5:14).

In the New Testament, healing and the Kingdom is closely related and healing can indeed be seen as the sign of the rule of Christ on earth (Luke 10:9). According to Christ, healing forms an integral part of his work on earth (Mt 11:4-6; Lk 4:4-20; Hurding 1995:431). In the Synoptic Gospels, no other facet of Jesus' ministry gets as much attention as his miraculous healings (König 2001:186). The discussion has already indicated that the Bible emphasises how God historically started countering and finally conquered sin in Christ. Similarly, Christ fought and conquered illness and evil spirit forces as symbols of evil (Blocher 1995:362). In the New Testament, there is a close link between demon possession and illness, and they are viewed as synonymous concepts. To expel demons is to heal someone (Acts 10:38). Understanding disease and psychosis within a reference frame of demonics forms part of the cultural context of the New Testament (Mt 17:18; Acts 10:38; 1 Jn 3:8). Even incapacity was linked to evil spirits (Mt 9:32-33; 12:22-24; 17:15-18; Lk 13:11). Christ's exorcism of demons and healing of sick people formed part of his special rule (Mt 12:28; Lk 11:9, 20). According to Verhey (2011:99), Christ's exorcism of demons should be seen as the destruction of evil by means of healing. Jesus healed a variety of incurable diseases: blindness (Mark 8:25; 10:52; John 9:7), deafness (Mk 7:35), muteness (Mt 9:33; Mk 7:35), spinal malformation (Luke 13:13), paralysis (Mk 2:12; 3:5; Lk 5:17-26), chronic skin diseases (Mk 
1:42; Lk 17:14) and water retention (Lk 14:4). Together with this, Christ also healed a variety of complex psychological and spiritual diseases and conditions that limit capacity (Mk 1:26-35; 5:1-20; 9:26-26; Lk 4:41). Christ also healed people that had died or were in the power of death (Lk 7:11-17, $21-22 ; 8: 49-56 ; 13: 10-13$; Jn 11:44). Jesus' healing of people is motivated by love and serves as a practical demonstration of compassion (Mt 14:14; Mark 15:19; Hurding 1995:431; König 2001:226; Beyer 1965 p. 130; Macaleer 2014:126, 194; Moltmann 1990:106).

\subsection{Kingdom for the incapacitated}

Like other marginalised groups in the Bible (the poor, widows), ill or disabled people or people without capacity are highlighted as groups that should receive special attention (Morphew 2015, loc 712). As the above examples of healing shows, children and the welfare of children form important aspects of the Kingdom (Mark 10:14; Morphew 2015, loc 696; Van Wyk 2015:198). In the Old Testament, clear references are found to disabled persons who are not forgotten by God (Jer 31:8). They may not be disadvantaged in any way (Lev 19:14), should be cared for (Job 29:12-17) and they are promised healing (Isaiah35:3-6). Moltmann (1990:109-110) points out that the crucified Christ, who was unable to help himself (Luke 23: 35), knows what incapacity entails. It is an incapacity that no human being can fully understand. Cochran (2011:232) is therefore of the opinion that the rule of Jesus (as is evident from the above healings) was especially focussed on the healing of children and persons with limited psychological capacity or no capacity, like the dead (Luke 14:15-24). People that depend on others are a special theme of the Kingdom (Mt 5:3; Van Wyk 2015). There are already indications of healing the entire person in the Old Testament, where shalom is linked with healing (Atkinson 1995:89; Jeremiah 8:15; Isaiah 3:5; Luke10:5-9). Healing by Jesus as an act of compassion is aimed at the total being (Moltmann 1990:108). Both the Greek words $\sigma \omega \zeta \omega$ and vүın', which are used for healing, are more often translated with 'whole' and does not only indicate the process of healing, but also the process of getting into a state of total physical, psychological and spiritual health (Mt 9:22; Mark 5:34; Lk 8: 48; Jn 5:6, 9, 11, 14-15; 7:23; Fohrer 1965:966-968; Foerster 1965:990). In the ancient Greek period, the word $\sigma \omega \zeta \omega$ also had the meaning of 'best interest' (Fohrer 1965:966-968). The human being as a whole does not only include the physical, psychological and spiritual 
aspects of healing, but also includes the social aspect when the possessed person in Mark 5 can return to his family after he has been healed (Macaleer 2014:122, 123, 127, 128, 130-131, 195-196).

Evans (1995:590) and Dowdy (2011:522) are of the opinion that the parable of the Good Samaritan (Luke 10:25-37) indicates that healing, care and substitute consent form part of the rule of God. For Hyland (2008:201) and O'Mathúna (2014), the parable has a definite bioethical focus and places the emphasis on someone that could not speak due to the absence of consciousness. He mentions that the narrative 'is an excellent example of the Christian ethic because he did for the victim...what the victim could not do for himself...' Mazur (2012:120) explains the Samaritan ethics as follows (see also Frame 1988:42-43):

Another parable, namely that of the Good Samaritan (Lk 10:30-37), can be invoked at this point, as well, because it fits precisely the theme of mercy in the context of substitute decision making. The Good Samaritan acts out of compassion and shows mercy to the wounded and robbed man. His role combines that of a proxy (he makes a decision on how to care for the man and then, after providing first care, gives directives to an innkeeper) with that of a physician (he himself bandages up the man's wounds). In both cases mercy underlies the Good Samaritan's actions.

It is not strange for the Kingdom that persons with capacity make decisions on behalf of people with no capacity. Frame (2008:683) is of the opinion that the fifth commandment (Ex 20:12) compels people with capacity and authority as guardians to be good to disabled persons in a position of inferiority. Parents do this in view of the best interest of their children (Ephesians 6:1-4; Morphew 2015:430-441). Like the healing during Jesus' work on earth, all healing forms public signs of the rule of Christ in the world (Hurding 1995:432, 434), also with the aim of convincing people of Christ's rule (Jn 20:30-31).

\subsection{Ethical assessment}

It is clear that the thought of sin and evil, firstly, forms an important subtheme in the Kingdom of God. This means, on the one hand, that people without capacity (or sick people), as acknowledged in Article 
7(b) of the UDBHR, are recognized as a reality within the Kingdom and receives special attention. On the other hand, sin underlines the possibility of evil perpetrated against persons without capacity within the research environment (Douma 1997:46; VanDrunen 2009:53-54). Article 7(b) is precisely formulated to acknowledge the possibility of evil in the area of research and to prevent it as far as possible. In this regard, Protestant ethics supports Article 7(b) of the UDBHR (see Childress 2002). Trust is not enough; therefore, research ethics should be presented in human rights terms (Van Wyk 1991; J.M. Vorster 2004:92, 111). It has furthermore become clear that a universal justice system aimed at protecting people is an important aspect of the Kingdom; therefore, the thought of special protection in the form of a universal code can be wholeheartedly supported.

In the second instance, human dignity, human freedom and substitute consent all form important points of departure within the Kingdom of God. In the light of this statement, the UDBHR's acknowledgement of human dignity of the person without capacity as a basis for that person's protection can be supported. In addition, the thought of human freedom also offers Scriptural justification for the concepts of participatory decision-making and refusal to take part in research as set out in Article 7(b). Douma (1997:109) is correct when he feels that medical illiteracy or incapacity should not be used as an excuse to ignore such a person's right to consent (Barry 2012:99; Mazur 2012:51). The point of departure of substitute consent can also be accepted as a norm of the Kingdom of God; therefore, the stipulation that no research may take place without consent is justified.

The question is, thirdly, if persons without capacity may be used in medical research where there is a direct health benefit. The global community is of the opinion that people without capacity can be involved in research in a responsible manner as stipulated in Article 7(b). The same idea is founded in the Kingdom of God where healing by Jesus is viewed as a direct health benefit in the form of the prevention, alleviation and healing of diseases as a duty of humanity (Douma 1997:49; Verhey 2011:100). This means that healing, medicine and the medical profession form part of the Kingdom of God and are special signs of the rule of God (Verhey 2011:738). God wants to transform people's lives through healing (Moltmann 2012, loc 1082). It is evident that people without capacity form a special part of the Kingdom 
of God, and they are entitled to healing and medical care (Douma 1997:51). The concept of research is not strange to the Kingdom either. It is seen as part of the calling of the human being as viceroy to make the earth inhabitable. Research is therefore the precursor to responsible healing and this is part of the Kingdom of God (Heyns 1986:325). Frame (1988:58), who is of the opinion that in Biblical terms, the duty to heal leads to the duty to do medical research, says the following:

In Biblical terms, medical research should be regarded as part of the process of healing people. As such, it has the same biblical mandate as medical treatment itself.

Research entails an indirect duty to discover the prevention, alleviation and cure of diseases (psychological, physical and social). Most research, as a form of healing, has a direct health benefit for the person. In the light of the fact that people without capacity form part of the healing narratives of the Kingdom, one can conclude that they may also be used for medical research. However, research that involves these persons should be conducted with respect (Kelly et al 2013). Furthermore, research is also founded on the duty of the researcher to do no physical, psychological or social harm to the person during the process of healing and to protect the person, especially when it comes to people without capacity, but who are created in the image of God. The only way to ensure that people are not harmed now or in future is through responsible research. The fact that research within the Kingdom is aimed at the whole person implies that research should not only be focused on the physical, but also on the psychological and social aspects of the person without capacity. It enables, for instance, research with children within the totality of the life sciences. Needless to confirm, as is logically evident from natural law, research may only be considered if research with persons with capacity is not possible or realistic. In the light of the application of an ethics of the Kingdom, it can be defended that Article 7(b) of the UDBHR includes people without capacity with a view to research, also because an exclusive protectionist approach can harm people without capacity (Childress 2002).

The fourth question, which comes to the fore, is whether research on people without capacity can be considered when there is no direct health benefit. There is ethical division on the matter. Prominent Protestant theologians 
like Paul Ramsey (1970) and James Childress (2002) are of the opinion that when someone does not have the freedom to provide consent, research may not be considered. Over and against this, May (2013, loc 4748-4754) from the Catholic traditions says that consent to do research with persons without capacity should not necessarily be viewed as unethical. Parents frequently take their children, including babies, with them in vehicles, even if the journey has no direct advantage for the children, for instance when buying clothes for the mother. Such journeys carry a certain minimal exposure to risks. These types of substitute decisions are seen as acceptable for both the person that makes the decision and the one for whom it is made (see also RCC 2009:21). De Bruyn (1993) and Douma (1992) judge from a Protestant perspective that Psalm 91 indicates that every person is exposed to danger every day; consequently, they assume that you can expose yourself and others, who are in your care according to the fifth commandment, to minimal risk without doing something unethical. The important regulating norm, according to Article 7(b), is that consent for research may only be provided if the experiment carries the minimum risk or burden. This norm links up with the principle of the Kingdom that the person without capacity, who is created in the image of God, may not experience any physical or psychological harm. Included in the command to heal, is the indirect command not to let people suffer and not to hurt them (Verhey 2011:100), and it links up with the command that people may not be physically or psychologically disadvantaged.

Protestants acknowledge, in the fifth instance, that believers have the calling to share in the rule of God. According to Wilkinson (1998:291-293), the church has the task to testify in the world and therefore faithful doctors, nurses, researchers and ecclesiastical structures should be socially involved by seeing that all global research on persons without capacity occurs within the guidelines of the Kingdom and Article 7(b) of the UNESCO declaration. The church, as co-workers in the Kingdom, has a ministry of healing (Cook 1995:437). According to Wilkinson, the promotion of bioethical principles in secular society can be viewed as a ministry of healing in a modern sense. 


\section{Conclusion}

It is clear that the global community views substitute consent with a view to research on persons without capacity as the right and duty of all communities. Substitute consent, as included in Article 7(b) of the UDBHR, can undoubtedly be maintained as a human right and ethical norm from a Protestant perspective, and it is therefore a command directed at the church and the wider society. Van Leeuwen (2014), who evaluated the UDBHR very shortly from a Protestant paradigm, can be fully supported when he says the following:

From the small overview of Protestantism above, it is possible to deduce the main points of concordance with the UNESCO Universal Declaration on Bioethics and Human Rights. The first ten articles of the declaration are in accordance with the recognition of personal, individual conscience and responsibility and with the communal aspects of Protestant religion and its emphasis on justice and being equal in the eye of God.

\section{Bibliography}

Atkinson, D 1995. Life, health and death. In New Dictionary of Christian Ethics \& Pastoral Theology. Downers Grove, Ill.: InterVarsity Press. 87-92.

Barry, V 2012. Bioethics in a Cultural Context: Philosophy, Religion, History, Politics. Boston, Mass.: Wadsworth Cengage Learning.

Barth, K 1976. The Doctrine of God, vol. 2. Edinburgh: Clark. 1955-1969.

Beauchamp, TL. \& Childress, JF 2013. Principles of biomedical ethics. New York: Oxford University Press.

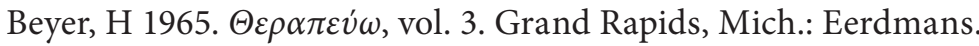

Childress, JF 2002. Protestant perspectives on informed consent, particularly in research involving human participants. Fordham Urban Law Journal, 30:187-206. [Online] Available: http://nwulib.nwu. ac.za/login?url=http://search.ebscohost.com/login.aspx?direct=true\&db=edsbl\&AN=RN 126379330\&site=eds-live 
Cochran, E (ed.) 2011. Dictionary of Scripture and Ethics. Grand Rapids, Mich.: Baker Academic.

Cook, ED 1995. Health and health care. In New Dictionary of Christian Ethics \& Pastoral Theology. Downers Grove, Ill.: InterVarsity Press. 435-437.

De Bruyn, PJ 1993. Die Tien Gebooie. Midrand, SA: Varia.

Douma, J 1992. De Tien Geboden: Handreiking voor het Christelijk Leven, met een bijdrage van JP Lettinga. Kampen: Van den Berg.

Douma, J 1997. Medische Ethiek. Kampen: Kok.

Dowdy, C (ed.) 2011. Dictionary of Scripture and Ethics. Grand Rapids, Mich.: Baker Academic.

Council of Europe 1997. The Explanatory Report to the Convention for the Protection of Human Rights and Dignity of the Human Being with regard to the Application of Biology and Medicine: Convention on Human Rights and Biomedicine. Strassbourg.

Evans, M 1995. Mercy. In New Dictionary of Christian Ethics \& Pastoral Theology. Downers Grove, Ill.: InterVarsity Press. 589-590.

Foerster, W 1965. $\Sigma \omega \zeta \omega$. In Theological Dictionary of the New Testament, vol. 7. Grand Rapids, Mich: Eerdmans. 980-1012.

Fohrer, G. 1965. $\Sigma \omega \zeta \omega$. In Theological Dictionary of the New Testament, vol. 7. Grand Rapids, Mich: Eerdmans. 965-980.

Frame, J 2008. The Doctrine of the Christian Life. Phillipsburg, NJ: Presbyterian and Reformed.

Frame, JM 1988. Medical Ethics: Principles, Persons and Problems. Phillipsburg, NJ: Presbyterian \& Reformed.

Gefenas, E \& Tuzaite, E 2014. Persons without the capacity to consent. In HAMJ ten Have \& B Gordijn (eds). Handbook of Global Bioethics. Dordrecht: Springer Science + Business Media. 85-103.

Green, JB 1995. The Kingdom of God. In New Dictionary of Christian Ethics \& Pastoral Theology. Downers Grove, Ill.: InterVarsity Press. 529-532. 
Heyns, JA 1986. Teologiese etiek, dl. 2/1: Sosiale etiek. Pretoria: NG Kerkboekhandel.

Higginson, RA 1995. Ethics of medical care. In New Dictionary of Christian Ethics \& Pastoral Theology. Downers Grove, Ill.: InterVarsity Press. 93-99.

Hurding, RF 1995. Healing. In New Dictionary of Christian Ethics \& Pastoral Theology. Downers Grove, Ill.: InterVarsity Press. 431-434.

Hyland, S 2008. Christian ethics. In E. Verstraete (ed). The Popular Encyclopedia of Apologetics: Surveying the Evidence for the Truth of Christianity. Eugene, Oreg: Harvest House.

IBC 2004. Eleventh Session [of the] International Bioethics Committee of UNESCO (IBC). Paris. [Online] Available: http://portal.unesco.org/shs/en/file s/7495/11103874181ReportCIB11_en.pdf/ReportCIB11_en.pdf

IBC 2008. Report of the International Bioethics Committee of UNESCO (IBC) on Consent. [Online] Available: http://unesdoc.unesco.org/ images/0017/001781/178124e.pdf

Kelly, D, Magill, G \& Ten Have, H 2013. Contemporary Catholic Health Care Ethics. $2^{\text {nd }}$ ed. Washington, DC: Georgetown University Press.

König, A 2001. Fokus op die 300 Geloofsvrae wat Mense die Meeste Vra: 'n Verwysingsgids vir Elke Huis. Wellington: Lux Verbi.

Langlois, A 2013. Negotiating Bioethics: The Governance of UNESCO's Bioethics Programme. Abingdon, Eng: Taylor and Francis.

Macaleer, RD 2014. The New Testament and Bioethics: Theology and Basic Bioethics Principles. Eugene, Oreg: Pickwick Publications.

Martin, J F 2009. Article 7: Persons without the capacity to consent. In $\mathrm{H}$ ten Have \& M Jean (eds). The UNESCO Universal Declaration on Bioethics and Human Rights: Background, Principles and Application. Ethics series. Paris: UNESCO Publishing. 139-153.

May, W 2013. Catholic Bioethics and the Gift of Human Life. $3^{\text {rd }}$ ed. Huntington, Ind.: Our Sunday Visitor. [Kindle ed.] 
Mazur, G 2012. Informed Consent, Proxy Consent, and Catholic Bioethics: For the Good of the Subject. Dordrecht: Springer.

Mcgrath, AE 1995. Sin and Salvation. In New Dictionary of Christian Ethics \& Pastoral Theology. Downers Grove, Ill.: InterVarsity Press. 27-32.

Moltmann, J 1990. The Way of Jesus Christ: Christology in Messianic Dimensions. London: SCM Press.

Moltmann, J 2012. Ethics of Hope. M. Kohl (trans.). Minneapolis, Minn.: First Fortress Press.

Morphew, D 2015. Kingdom Theology and Human Rights. Kingdom theology series. Createspace. [eBook].

Nullens, P 2013. 10 Woorden van Leven. Heerenveen: Uitgeverij Medema.

O’Mathúna, DP 2014. Christian bioethics and the Bible. Christian Bioethics, 20(2). doi:10.1093/cb/cbu017

Ramsey, P 1970. The Patient as Person. New Haven, Conn.: Yale University Press.

RCC 2009 see United States Conference of Catholic Bishops.

Sentamu, JM 1995. Torture. In New Dictionary of Christian Ethics \& Pastoral Theology. Downers Grove, Ill: InterVarsity Press. 852-854.

Ten Have, H 2011. Bioethiek zonder Grenzen: Mondialisering van Gezondheid, Ethiek en Wetenschap. Antwerpen: Valkhof Pers.

Ten Have, H \& Jean, M 2009. Introduction. In H ten Have \& M Jean (eds). The UNESCO Universal Declaration on Bioethics and Human Rights: Background, Principles and Application. Ethics series. Paris: UNESCO Publishing. 17-57.

Tham, J 2014. Introduction: the principle of vulnerability: meeting ground of six religions. In J Tham, A Garcia, \& G Miranda (eds), Religious Perspectives on Human Vulnerability in Bioethics. Advancing global bioethics, 2. Dordrecht: Springer. 1-7. 
Ucko, H 2014. Christian perspective on vulnerable groups: the elderly and the disabled. In J Tham, A Garcia, \& G Miranda (eds), Religious Perspectives on Human Vulnerability in Bioethics. Advancing global bioethics, 2. Dordrecht: Springer. 143-151.

UNESCO 2005. Explanatory Memorandum on the Elaboration of The Preliminary Draft Declaration on Universal Norms on Bioethics. [Online] http://unesdoc.unesco.org/images/0013/001390/139024e.pdf

UNESCO 2006. Universal Declaration on Bioethics and Human Rights. [Online] Available: http://unesdoc.unesco.org/images/0014/001461/146180e.pdf

UNESCO 2008. Bioethics Core Curriculum, Section 1: Syllabus Ethics Education Programme. Sector For Social and Human Sciences Division of Ethics of Science and Technology. [Online] Available: http://unesdoc.unesco.org/images/0016/001636/163613e.pdf

UNESCO 2011. Bioethics Core Curriculum, Section 2: Study Materials Ethics Education Programme Version. [Online] Available: http://unesdoc. unesco.org/images/0021/002109/210933e.pdf

UNESCO 2013. Casebook on Bioethics and the Holocaust.

[Online] Available: http://www.unesco-chair-bioethics.org/UI/F0101. aspx?uid=F8D02FF3F880A4FE

United States Conference of Catholic Bishops 2009. Ethical and Religious Directives for Catholic Health Care Services. $5^{\text {th }}$ ed. Washington, D.C. [Online] Available: http://www.usccb.org/issues-and-action/human-life-anddignity/health-care/upload/Ethical-Religious-Directives-Catholic-Health-Care-Servicesfifth-edition-2009.pdf

Van Leeuwen, E 2014. Protestantism. In HAMJ ten Have \& B Gordijn (eds). Handbook of Global Bioethics. Dordrecht: Springer Science + Business Media. 419-427.

Van Wyk, JH 1991. Etiek en Mensregte: Moraliteit en Verantwoordelikheid: Opstelle oor Politieke Etiek. Potchefstroom: Dept Sentrale Publikasies, PU vir CHO. 253-266.

Van Wyk, JH 1998a. Debat oor Menseregte: Etiek in Eenvoud: Gesprekke oor Morele Vraagstukke. Noordbrug: Potchefstroomse Teologiese Publikasies. 174-176 
Van Wyk, JH 1998b. Etiek en Menseregte: Etiek in Eenvoud: Gesprekke oor Morele Vraagstukke. Noordbrug: Potchefstroomse Teologiese Publikasies. 170-173.

Van Wyk, JH 2015. Teologie van die Koninkryk: Studies in Dogmatiek en Etiek. Pretoria: V\&R.

VanDrunen, D 2009. Bioethics and the Christian life: A Guide to Making Difficult Decisions. Wheaton, Ill: Crossway.

VanDrunen, D 2014. Divine Covenants and Moral Order. A Biblical Theology of Natural Law. Grand Rapids, Mich: William B. Eerdmans.

Verhey, AD (ed) 2011 Dictionary of Scripture and Ethics. Grand Rapids, Mich: Baker Academic.

Verhey, AD 2013. Overview: ethics in Scripture. In JB Green \& JE Lapsley (eds). The Old Testament and Ethics: A Book-by-Book Survey. Grand Rapids, Mich: Baker Publishing. 1-14

Vorster, JM 2004. Ethical Perspectives on Human Rights. Potchefstroom: Potchefstroom Theological Publications.

Vorster, JM 2011. Menswaardigheid, Versoening en Vergiffenis.

Potchefstroom: Potchefstroomse Teologiese Publikasies.

Vorster, JM 2015. Christelike Etiek in ' $n$ Sekulariserende Samelewing. Durbanville: AOSIS.

Vorster, N 2003. Kerk en Menseregte binne 'n Regstaat. Potchefstroom: Potchefstroomse Teologiese Publikasies.

Vorster, N 2007. Restoring Human Dignity in South Africa: Christian Anthropology in a New Dispensation. Potchefstroom: Potchefstroom Theological Publications.

Wilkinson, JMD 1998. The Bible and Healing: A Medical and Theological Commentary. Edinburgh: Handsel Press. [Online] Available: http:// www.oxfordjournals.org/our_journals/cb/for_authors/msprep_submission.html 



\title{
Polluted water, stinking water, frozen water, no water: A life threatening situation! Perspectives from Exodus 1-11 and 15-17
}

\author{
Van der Walt, Steven \\ University of the Free State \\ ideo@caw.ac.za
}

\begin{abstract}
The article highlights the life threatening consequences Israel could have faced if they did not stay within the creational rhythm which YHWH planned for them. Natural phenomena, in which water played a significant role, contributed to these life threatening circumstances. Certain pericopes of two external narratives (Ex 1-14; Ex 15-18) form the backbone of this article. Natural phenomena (transformation of water) are being used to highlight the fact that YHWH alone is creator God: live according to His ordinances (rhythm) and be assure to be blessed; do not live accordingly, and be assure that the natural rhythm of nature could turn upside down with devastating consequences such as polluted water, stinking water, frozen water or, no water at all. It turns out that being without life-giving water is just as dangerous as being without YHWH, thus a life threatening situation.
\end{abstract}

\section{Introduction}

The viewpoint of this paper stems from the assumption that nature and its natural phenomena within, have but one author, YHWH. YHWH is creator, not only of the cosmos and the world, but of life (Fretheim 1991a:385-386). To be more specific, YHWH created life, but according to the Hebrew bible, also created for Himself a people. The aim of this paper is to indicate that there were important aspects with regard to the rhythm between YHWH's creation and his people, living life as His people. Moving beyond that rhythm had life threatening consequences, in which natural phenomena played a significant role.

1 This article was read as a paper at the OTWSA conference hosted by UNISA at Kwalata Lodge, Gauteng, on 2 September 2015. 
Deuteronomistic history gives ample examples of a disturbed rhythm which lead to life threatening circumstances. During Israel's time of exile (587 BC), Israel did what many people do in times of difficulty: became introspective. One way of being introspective is to ask questions: What went wrong? Or, what happened? Or, what is the reason for our being in this crisis situation? For Israel, the crisis of the Babylonian exile brought remembrance of things past - or in the words of some, 'Chronicles of memory' (Crites 1971:298). The memory of YHWH's creational power, great redemptive acts and promises comforted Israel in times of distress. It reminded them that their being there, in distress, had also been the result of a disturbed creational rhythm, in which they had to take blame upon themselves as well.

Fragments of two external narratives (as told by the narrator/s of the Deuteronomistic history) form the backbone of this paper. In the first narrative (Ex. 1-14) YHWH uses miraculous acts to create for Himself a people and to deliver them from bondage through His agent Moses. Natural phenomena are used to highlight the fact that YHWH alone is creator God: live according to His ordinances (rhythm) and be sure to be blessed; do not live accordingly, and be assured that the natural rhythm of nature could turn upside down with devastating consequences (polluted water, stinking water, frozen water), as was the case with regards to Egypt.

The second narrative (Ex 15-18) heralds the so called 'Wilderness tradition'. A water motif is being used to show Israel that the same God who turned nature 'upside down' in Egypt, is able to restore nature to its healthy origins. Israel is then being invited, but also warned to stay within the rhythmic boundaries which YHWH has set for them (Ex 15:26).

\section{Creation turned upside down}

\subsection{Pharaoh's mistake}

The narrative problem of Exodus is defined in Exodus 1. Pharaoh enslaved the Israelites and forced them to build his store cities (Ex 1:8-14; 5:1-23). In doing so, Israel glorified Pharaoh's reign, 'and not the reign of the God whose servants they are as descendants of Abraham' (Leder 2010:95). Pharaoh's act of enslavement (Ex 1:11) was also intentional. He tried to prevent the Israelites from multiplying. The 'future of YHWH's promises 